\title{
A Bachelardian Reading of Marie de France's Guigemar
}

\section{Ingrid HORTON}

I

$\mathrm{n}$ the prologue to her lays, Marie de France invites the reader to furnish his/her own interpretation of the text. She believes that meaning is not fixed in stone, but changes throughout the ages. Sturges, in his Medieval Interpretation: Models of Reading in Literary Narrative, 1100-1500, remarks of medieval texts: "[. . .] these medieval works are not merely conceptually incomplete; they insist upon their own incompleteness, upon the gaps that make interpretation not only possible but necessary [...]" (2). I would like to attempt to explore one of these gaps in reexamining the symbolic space in Marie's Guigemar, which has been widely discussed, yet not fully explicated by critics. I have chosen Gaston Bachelard's phenomenological theories as a point of entry. In my opinion, Bachelard provides a flexible model that suggests strategies for exposing the polyvalent meanings of each individual work. I am particularly interested in his book, La poétique de l'espace, where he examines images of a dream-like house (maison onirique) and a birth house (maison natale) evoked in his book La terre et les rêveries $d u$ repos. These archetypes not only aid in discovering the multiple meanings of a text, but also link the meanings. Thus, they allow the reader to instantly penetrate a text in an insightful manner. As a case in point, Bachelard's work is particularly useful in examining the way Marie de France utilizes symbolic space in Guigemar. 
The house according to Bachelard is a privileged place: "[it] protects us. One cannot write the story of the human subconscious without writing a story of the house"1 (La terre et les revveries du repos 115 ). Thus, the birth house is the actual childhood house, the one that recalls the protection of the parental abode: it is the essence of every being. Using the birth house as a point of reference, one creates the dream-like house that is "[. . .] an image which, in memory and in dreams, becomes a protective force [.. . It protected us, thus it still comforts us" (ibid 119). Consequently, this house is an idealized space that seems more perfect the more one is removed from it.

Bachelard's concentration on the past does not allow emphasis on dreaming about the future. One does not dream only of the past but also of what is to come. If the place inhabited in the present is not what one had hoped, one imagines an ideal house to be occupied in the future. This vision represents a possibility of an improvement of the situation and hence, also becomes a privileged place. In the case of Guigemar, it is the future that is problematic. Ostensibly, his birth house lacks nothing, yet he dreams of someplace else that is even more perfect. Guigemar allows one to hypothesize a third archetypal house I would like to call cosmic. This house integrates a magical world, tying the daydreamer to the future.

What does "the poetry or poetics of space" mean in Guigemar? And how will it help in interpreting its poetic images? For Gaston Bachelard, poetry is found not only in written language but also in the images evoked by this language. His phenomenology of the imagination (or of the image) evaluates the effect of a poetic image on the reader-that is to say, the scope, the strength and the meaning of this transsubjectivité de l'image, or communication of souls through images. However, this effect is not universal. So, how does one critique a phenomenon that is not tangible? Bachelard attempts to answer this question by stating: " $[$. . . ] one asks the reader of poetry to not take an image as an object, or even as a substitute for an object, but to grasp the specific reality" (La poétique de l'espace 3 ). Consequently, before approaching a work, one must forget all knowledge that could interrupt the transfer of the image from the soul of the author to the soul of the reader. This transsubjectivite de l'image is produced through the double phenomenon of resonance and impact. Resonance, he claims, touches on every aspect of life, whereas impact is described as transfer of the soul; it is the moment when the poetic being of the author and the reader merge, mediated by the image. The reader is so absorbed in the image that a poetic imagination is awakened in his 
soul and he has the impression that he could have created the image himself. The phenomenologist must determine the significance of this source, i.e., the image.

In his book, La poétique de l'espace, Bachelard investigates the significance of the image's literary space by exploiting different sorts of "locus amoenus" not only from the human point of view but also from that of birds and even of mollusks. Bachelard disallows the term " topoanalysis", preferring the word "topophily" which examines a "happy" locus and which determines the importance of one's environment, of one's territory, of cherished spaces. However, according to him, theses spaces are often glorified in the imagination, and their meaning is thus idealized. This exact phenomenon incites the journey of our eponymous hero.

Guigemar, a mercenary interested only in war and hunting, returns home for a visit with his parents. During his stay, the desire to hunt overcomes him, so he heads for the forest. In general, one understands that in this lay, Marie de France represents metaphorically the process of growing up (The Lays of Marie de France Hanning 55). However, according to Bachelard's method, one must forget these metaphors and concentrate on the images, which is what I will attempt to do. First, disappointed that his birth house does not live up to his memory of it, Guigemar leaves his parent's house on a whim. His disillusionment leads him to abandon a familiar, enclosed space, where he had hoped to find stability and shelter, to go towards a mysterious and limitless unknown: he seeks a cosmic house. The longing that envelops him is not one to hunt but rather to love; this desire surges forward after many years of denial. However, as he has never felt this way before, he does not understand and mistakes this new sensation for a need to do what he normally did: destroy. Thus, upon spying a great deer, he decides to slaughter it; he is struggling to conquer not only Mother Nature but also his own nature, believing that he can somehow repress his sexuality.

In this savage wood, full of possibilities, Guigemar seeks to subdue what he cannot control: his passions. And it is only "in the space of a large shrub" (5) that he finds the animal that he pursues. As in many courtly romances, the forest is where Nature overcomes culture and in its density, hides the dangers that await the hero. This thicket could be interpreted as a sort of nest which, according to Bachelard, "[. . .] found in nature [.. . ] [can introduce] the center of the universe, the element of a cosmic situation" (La poétique de l'espace 95-96). In Guigemar's case, I would say that by investigating the thicket, he comes into contact with a 
magic realm of being, a dream-like state which projects him into another universe. The forest in which he roams is what Bachelard designates as "an intimate vastness" which he explains by remarking: "[. . .] the contemplation of greatness creates such a unique approach, a state of the soul so distinct that the day dream places the dreamer outside of the next world, in the presence of a world that bears the mark of a perpetuity." (ibid 168). Although extremely gifted in the art of the hunt, Guigemar does not succeed in dominating his yearning; instead, by loosing his arrow, fate is sealed.

The curse of the doe that has the horns of a buck adds another dimension to Guigemar's quest: he must seek out love. The androgyny of the deer mirrors Guigemar's own unidentified sexuality and its death signifies the end of Guigemar's childhood and serves as a catalyst for his entry into maturity. In my opinion, what is interesting here is not the malediction, but his reaction: "He began to think; in what land he could go, to find a cure for his wound" (125-27). The curse of the deer does not consist of a physical voyage but a spiritual voyage. However, Guigemar understands it literally as he has never seen a woman to whom he could offer his love. Because love is unknown territory for him, he knows that he cannot stay in his own country (the birth house). He understands that he must travel towards a mysterious country (the cosmic house) in order to be cured. He feels impatient to depart on his quest for a remedy not only for his wounded thigh, but also for his passions. Accordingly, he allows his desires to guide him through the woods without knowing exactly where he is going.

After leaving the forest, he approaches a bay where he finds a ship. However, he does not find an ordinary ship, but one that comes from an unknown realm. It is a dream ship: "The dowels and the spikes were all made of ebony, No treasure in the world was worth more. The sail was made all of silk, and greatly beautiful when deployed" (156-60). However, it is not only the décor that renders it dream-like, but also its means of navigating without a pilot. This ship functions as a transitional house, allowing him contact with his subconscious that will lead him to his destiny. Upon boarding this vessel, Guigemar finds a richly decorated bed. Feeling tired, he lies down and falls asleep. In my opinion, the dreams that occur during his sleep lead him to the lady. The creative energy of the sea invades his sleep when he is no longer able to put up any resistance; therefore, his desires and his need for a cure steer this ship towards the hoped for, yet unknown kingdom. By embarking on this ship, 
he finally accepts his passions and allows them to direct him toward his destiny.

In this new world, there is a tower that is a good example of an attic or the top floors to which Bachelard refers. "The roof immediately expresses it's raison d'être: it shelters man who fears the rain and the sun [...] the dreamer himself dreams rationally [...] towards the roof all thoughts are clear" (La poétique de l'espace 35). So, it is a place that encourages dreams but not those that are unattainable. However, before Guigemar's arrival, this tower functions as a prison for the lady. Although her body is held captive, this lofty enclosure permits her imagination to flourish and ultimately leads her to love.

For Guigemar, here, in this elevated space of the tower, he accomplishes his goal. He no longer attempts to destroy his passions, but rather, he allows them to exist and deepen, and ultimately, they are more that just passions, they develop into love. This tower has only two ways of entering it: from the sea or through a chapel guarded by a castrated priest. Here, one encounters the efforts of a jealous husband to control Nature. According to Semple in his article "The Male Psyche and the Female Sacred Body in Marie de France and Christine de Pizan.": "Everything about the environment of the Lady suggests an attempt to control female sexuality and to imprison the female body...through the presence of religion" (174). Since religion implies a system of censure, the husband uses it as a means to exclude entry to the tower. In other words, when one enters the chapel, one finds oneself in the presence of iconic images that stir up feelings of morality and a wish to behave properly because one is in the "house of God." However, the jealous husband does not trust the power of religion with regard to his wife because he places a guard in front of the entrance. This poor priest on guard has been castrated as a means of further assurance of the lady's virtue.

In the tower, the lady's room is situated: "The room was completely painted: Venus, the goddess of love was placed in the painting, She showed the qualities and nature of love and how man must serve and be loyal to it" (233-38). This painting shows Venus throwing Ovid's Remedia amoris in the fire. Evidently, the husband wants his wife to learn how to love by means of this fresco. However, the jealous hushand lacks imagination and interprets this painting on a very superficial level. This painting is an example of a microcosm, which Bachelard calls a "miniature." He explains "[. . . ] One must understand that in the miniature the significance is condensed and enriched [...] one must surpass life's logic to see that there is something great in what is little." (La poétique de 
l'espace 142). The husband considers himself a sort of despot and assumes that the message of Venus includes rules that one must follow in order to be a good lover; and in a way, he is right. However, it is not the lover who is to be served, but Venus herself. In addition, by flinging the Remedia amoris in the fire, she repudiates efforts to contain both Mother Nature and love in order to conform to society. Thus, this painting encourages the contrary of what the husband had anticipated.

Finding Guigemar hurt and asleep in the ship, the lady escorts him to her room to care for the wound in his thigh, swearing to him that he can remain there until he is able return home. As for Guigemar, at first sight of the Lady, he realizes that he is in a foreign realm where he is to be nursed back to health by a woman. Immediately, under Venus' watchful eye, in the middle of the cosmic house, he receives a wound to his heart: he falls so in love with the lady that he completely forgets his birth house. According to Gertz: "[...] Marie allegorizes the attempt of the goddess of love to close, to control communication. In other words, it seems an impulse of love to encourage lovers to isolate themselves from the society of others and develop their own forms of communication" (384). Therefore, following Venus's commands (and ignoring Ovid's advice in his Remedia amoris), the Lady hides Guigemar behind a curtain.

The two isolate themselves and develop a language of love. Bachelard calls this type of solitude "roundness" explaining, "[ . . .] what isolates itself becomes rounded, takes the form of the being which is concentrated on itself." (La poétique de l'espace 214) Yet, in the case of Guigemar and the Lady, they do not concentrate on themselves but on each other and nature. Without any external impositions of society and of the husband, their desire, their passions, their nature begin to burn and to destroy social restrictions. Enclosed together in the Lady's room, they find a happiness that they had never known before; in other words, they finally experience what Bachelard calls a topophily.

Although there is a dialogue between the lover's souls that does not mean that they are not sensitive to society's constraints. One day, after awakening, the Lady announces to Guigemar: "My heart says that I will lose you" (547). I understand here another miniature: a miniature of two worlds that cannot exist at the same time without reacting on each other. Bachelard explains: "[...] in the order of hearing, we have an immense, echoing miniature, that of an entire cosmos which speaks softly" ( $\mathrm{La}$ poétique de l'espace 162). In my opinion, the voice that the lady hears emanates from the world of her husband; in order to hear it, one must first know how to listen. For Bowers: "Since any activity that a man and a 
woman needed to keep private could be considered antisocial, suspicion naturally arose that such activities needed to be brought to light as sinful or criminal" (1). By falling in love with Guigemar, the lady learns how to listen to what is not expressed out loud: the suspicions of her husband. In other words, before Guigemar's arrival, the lady heard endlessly the religious lessons on how to be a good wife. However, after his arrival, she still listens to them, but she also listens to the lessons of love; love needs no words to be heard.

In fact, the premonition of the lady comes true; the jealous husband chases Guigemar from his country and encloses the lady in a tower of dark marble where she lives for two years. Because she longs for Guigemar so much, she often laments. She wishes to kill herself and on a whim, she attempts to open the door. For Bachelard, the door is "a cosmos of the half open" (La poétique de l'espace 200). This means that when a closed door presents itself, there is always a temptation to open it, and when the door is open, one wants to close it. The door itself represents a world of contradictory feelings. Closed, one wants do discover what is on the other side...curiosity dominates until one decides to finally open it. Open, one wants to keep what is on the outside from entering. It is the fear of the unknown that provokes this desire to close the door.

Yet, as for the lady, she suffers so greatly from the separation of her lover that she no longer fears anything... she decides to escape and the easiest way is the door: "Lost, she goes to the door and finds neither lock nor key; by chance, she leaves" (674-76). Thus, one must wonder: Was the door always open and the only reason that she stayed there so long is that she just never before dared to try to escape? I would say that it is her lack of imagination that kept her imprisoned more than her husband. She must await a sort of daydream of the cosmic house (death or what Bachelard calls "the cellar," a descent into the unconscious) in order to be able to turn the knob of the door and to confront the dangers awaiting her on the other side.

She wanders to the sea to the place where she wishes to drown herself. There, she finds the ship that had brought Guigemar to her and boards it. Without a pilot, the ship embarks, taking her to the land where her beloved could be found. Unfortunately for her, Meriaduc, the lord of that land, spies the ship in his harbor, discovers her aboard, immediately falls in love and thus, imprisons her in his castle. Despondent, she no longer has the desire to dream and consequently, makes no attempt to escape this gilded cage. The lady's new abode does not constitute a Bachelardian "house" for her because there are no feelings attached to it. 
At a tournament, the two lovers rediscover each other, but Meriaduc, intensely jealous, refuses to allow the lady to leave with Guigemar. In order for the lady to be able to daydream again of a cosmic house, of a "happy place". Guigemar must destroy Meriaduc's chateau and free, both physically and spiritually, his beloved.

It seems to me that the image of the door the lady opens to escape her husband proves to be a good metaphor for the phenomenology of the imagination of Bachelard (despite the fact that he ignores the use of metaphors.) One must open the door of the imagination to be able to experience the beauty of the image... one must leave behind all that one knows in order to find this new world of creativity. Sometimes, one recognizes the poet's soul as one's own; and sometimes, one just cannot seem to experience the dream house of the poet. However, for Bachelard, what is important is not that everyone experiences the same thing from the same image; it is that the souls can communicate... one must find one which shares the same dream house.

University of Kansas 


\section{Note}

1. Translations of Bachelard's works and Guigemar (from the Ewert edition) are my own.

\section{Works Cited}

Bachelard, Gaston. La poétique de l'espace. Paris: Presses Universitaires de France, 1958.

-. La terre et les rêveries de la volonté. Paris: José Corti, 1948.

Bowers, John M. "Ordeals, Privacy, and the Lais of Marie de France." Journal of Medieval and Renaissance Studies 24.1 (1994): 1-31. de France, Marie. Lais. Ed. Alfred Ewert. Oxford: Basil Blackwell, 1978.

-. The Lais of Marie de France. Trans. and Ed. Robert Hanning and Joan Ferrante. New York: E.P. Dutton, 1978.

Gertz, Sunhee Kim. "Echoes and Reflections of Enigmatic Beauty in Ovid and Marie de France." Speculum 73 (1998) 372-96.

Sturges, Robert S. Medieval Interpretation: Models of Reading in Literary Narrative, 1100-1500. Carbondale: Southern Illinois University Press, 1991.

Semple, Benjamin. "The Male Psyche and the Female Sacred Body in Marie de France and Christine de Pizan." Yale French Studies 86 (1994): 164-78. 
